\title{
Clinical utility of patiromer, sodium zirconium cyclosilicate, and sodium polystyrene sulfonate for the treatment of hyperkalemia: an evidence- based review [Erratum]
}

\author{
Beccari MV, Meaney CJ. Core Evid. 2017;12:11-24.
}

On page 12, in the "Core evidence clinical impact summary for patiromer, sodium zirconium cyclosilicate, and sodium polystyrene sulfonate in the treatment of hyperkalemia" section, the "Implications" text for "Patient-oriented evidence" was incorrectly listed as: "Iloperidone was more effective than placebo and similar to haloperidol, risperidone, and ziprasidone in several psychometric scales and in symptoms assessment."

\section{Core Evidence}

\section{Publish your work in this journal}

Core Evidence is an international, peer-reviewed open-access journal evaluating the evidence underlying the potential place in therapy of drugs throughout their development lifecycle from preclinical to post launch. The focus of each review is to evaluate the case for a new drug or class in outcome terms in specific indications and patient groups.
The correct details are: "Patiromer and ZS-9 allowed for the initiation, titration, and maintenance of renin-angiotensinaldosterone system inhibitor therapy in patient populations that derive significant benefit, such as chronic kidney disease and heart failure. The ability of SPS to maintain normokalemia during renin-angiotensin-aldosterone system inhibitor continuation or dose titration is unclear."
The manuscript management system is completely online and includes a very quick and fair peer-review system, which is all easy to use. Visit http://www.dovepress.com/testimonials.php to read real quotes from published authors. submit your manuscript Dovepress $f$ in 